\title{
Seasonal variation in rooting potential of Kurume azalea "Chikushibeni" (Rhododendron Kurume group)
}

\author{
Masataka Yamashita and Akihide Okamoto \\ National Agricultural Research Center for Kyushu Okinawa Region, Kurume, Fukuoka 839-8503, Japan \\ Corresponding author: M. Yamashita, E-mail: my898@affrc.go.jp
}

Received on November 2, 2007; Accepted on August 25, 2008

\begin{abstract}
Kurume azaleas (Rhododendron Kurume group) are susceptible to environmental stresses such as drought, high temperatures, and soil physical and chemical conditions. We inferred that this susceptibility depends largely on their rooting potential. The rooting rate, the number of new roots, and root regenerating potential (RRP) obtained by incubating lignified root cuttings deteriorated remarkably or reduced during June and August. During summer, rooting did not respond to 1-naphtyleacetic acid (NAA) application. Reserve carbohydrates in the xylem tissue almost disappeared during June and August. These facts suggest that the rooting potential of root systems was distinctively low during summer. New root formation was inferred to be dependent on physiological conditions of parental roots, not only on external stresses, such as drought and high temperatures. In Kurume azalea, seasonal variation in rooting potential might be a major factor determining damage by environmental stresses.
\end{abstract}

Keywords: susceptibility to environmental stress, Kurume azaleas, Rhododendron Kurume group, rooting potential

\section{Introduction}

Kurume azaleas (Rhododendron Kurume group) are evergreen shrubs bred in the Kurume region of Kyushu, Japan; they are characterized by small to medium-small flowers with bright colors and numerous flowers covering the entire crown during the blooming period. In Japan, they are popularly grown as flowering shrubs for private and public gardens. It is widely accepted that they are susceptible to environmental stresses such as drought, dampness, high temperatures, and physical and chemical conditions of the soil (Horiguchi, 2002). They often do not grow well after transplanting (Arakawa, 1975), which has been revealed as a drawback in cultivation because they have become widely used for urban greening as a roadside landscape plant in recent years. Nevertheless, their susceptibility to stress has been little examined scientifically. We attempted to verify their susceptibility to stress from the viewpoint of root formation.

\section{Materials and Methods}

An experiment was conducted during April 2006 February 2007 using three-year old clonal plants of Kurume azalea "Chikushibeni" obtained from a commercial nursery. The cultivar was bred in 1989 by crossing original cultivars and "Karafune" azalea. Five plants were used to investigate rooting ability every two months. Roots of each plant dug out with a clod of soil (about $20 \mathrm{~cm}$ in diameter and about $20 \mathrm{~cm}$ in thickness) were washed with tap water and 10 lignified root cuttings $(50 \mathrm{~mm}$ long and about $1 \mathrm{~mm}$ thick) per plant were gathered from each root system. They were immersed for $4 \mathrm{~h}$ in $25 \mathrm{mgL}^{-1}$ NAA solution, which was the most effective concentration to induce rooting from lignified root cuttings (Yamashita and Okamoto 2008) after removal of existing lateral roots. Thereafter, they were obliquely embedded in wet vermiculite and incubated at $22^{\circ} \mathrm{C}$ for 30 days in darkness. After incubation, the cuttings that produced new lateral roots $(\geq 1 \mathrm{~mm}$ long) were registered and the new lateral roots $(\geq 1 \mathrm{~mm}$ long) per cutting were counted. The root regenerating potential (RRP) was calculated by multiplying a rooting rate index (RRI) and a root number index (RNI). RRI was based on (1) $0-30 \%$ rooting percentage, (2) 30-60\% rooting percentage, (3) 60-90\% rooting percentage, (4) $90-100 \%$ rooting percentage, and (5) $100 \%$ rooting percentage, and RNI was based on (1) 0-2 roots, (2) 2-4 roots, (3) 4-6 roots, (4) 6-8 roots, and (5) 8 or more roots per 10 -mm-long root cutting (Yamashita and Okamoto 2008). Root tissues were observed using about 1-mm-thick lignified roots 
gathered at each time. Several 50-60 $\mu \mathrm{m}$ thick cross sections were sliced using an auto-microtome (MT-3; NK System, Osaka, Japan) without any pretreatment. Thereafter the sections were treated with potassium iodide iodine solution to stain amyloplasts in tissues and observed immediately using an optical microscope.

\section{Results and Discussion}

Figure 1 depicts rooting (a) and non-rooting (b) lignified root cuttings. Rooting was observed within a week after incubation and rooting cuttings maintained freshness (Fig. 1a). Most non-rooting cuttings suffered necrosis of the superficial parenchyma during incubation. The rooting rate in April was $100 \%$ and about 20 new roots were produced per cutting, but the rooting rates in June and August deteriorated to $0 \%$ and showed necrosis during incubation, thereafter, the rooting rate increased in October and reached up to $90-100 \%$ in December and in the following year in February, during this time they produced about 30 new roots per cutting (Table 1). The RRP refers to the comprehensive root regenerating ability of parental roots that can be estimated by a combination of several factors such as the rooting rate, the number, and weight and length of new roots (Yamashita 1989). The RRP in the experiment was calculated based on two factors: RRI and RNI. The RRP throughout the year was highest in February, followed by April. In October and December, the rooting rate increased but RRPs were low because the quantities of new roots were small.

Reserve carbohydrates (amyloplast) in xylem parenchyma of roots were negligible in June and August, but they increased in October and were observed in abundance in December and February (Fig. 2).

Kurume azaleas have shallow root systems that consist of a few thick lignified roots and numerous fibrous roots (Arakawa 1975, Horiguchi 2002). The root system structure might be related to their susceptibility to various environmental stresses, such as excess or deficit of soil moisture, excess of nutrients, and increased soil pH (Horiguchi 2002). Tolerance of plants to environmental stresses is classifiable into two properties: physiological resistance to inadequate conditions and recovery from damages by stress. In this study, the susceptibility of Kurume azaleas to environmental stress was examined in relation to the latter factor. Root pruning can be an effective treatment to improve growth and yield and active root regeneration was induced by root pruning in several woody plants (Mullin 1966, Eis 1968, 1973, Yamashita 1989). Therefore, the rapid restoration of plant vigor depends mainly on root regeneration after
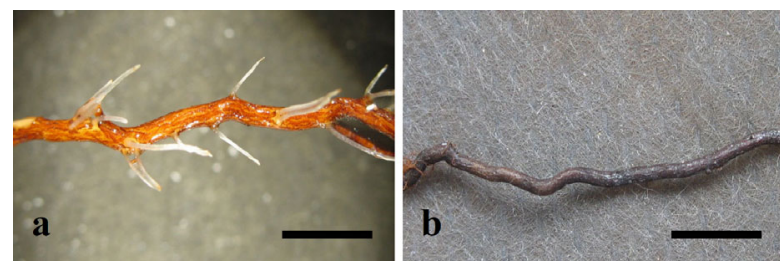

Fig. 1. Root regeneration from lignified root. a. Rooting (February). b. No rooting (August). Scale bars in figures are $10 \mathrm{~mm}$ long.

Table 1. Seasonal changes in rooting from lignified root cuttings

\begin{tabular}{lrrr}
\hline Month & $\begin{array}{l}\text { Rooting rate } \\
(\%)\end{array}$ & $\begin{array}{l}\text { Number of } \\
\text { roots }^{\dagger}\end{array}$ & $\mathrm{RRP}^{\dagger \dagger}$ \\
\hline April & $100.0^{\mathrm{a}}$ & $17.9^{\mathrm{b}}$ & $10^{\mathrm{b}}$ \\
June & $0.0^{\mathrm{d}}$ & $0.0^{\mathrm{e}}$ & $0^{\mathrm{e}}$ \\
August & $0.0^{\mathrm{d}}$ & $0.0^{\mathrm{e}}$ & $0^{\mathrm{e}}$ \\
October & $44.0^{\mathrm{c}}$ & $2.3^{\mathrm{d}}$ & $2^{\mathrm{d}}$ \\
December & $88.0^{\mathrm{b}}$ & $10.5^{\mathrm{c}}$ & $6^{\mathrm{c}}$ \\
February & $100.0^{\mathrm{a}}$ & $31.3^{\mathrm{a}}$ & $20^{\mathrm{a}}$ \\
\hline
\end{tabular}

\footnotetext{
${ }^{\dagger}$ Number of roots per root cutting.

$\dagger$ Root regenerating potential.

Different alphabet letters within a factor indicate significant difference at the $5 \%$ level (analysis of variance).
}

root pruning. We supposed that the susceptibility of Kurume azaleas to environmental stress was derived directly from root regeneration under stresses due to transplantation and poor growth conditions, which were accompanied by root pruning or physiological root loss. Judging from the results of rooting rate or number of new roots, the rooting ability of Kurume azalea was extremely low during summer (June to August). Furthermore, the rooting ability in October recovered slightly but remained insufficient for active regeneration. This phenomenon was more clearly apparent for RRP estimated with the product of two indices, which suggested that rooting ability was too low to recover from root damages rapidly during summer through early winter. Annual variation in RRP demonstrated that the rooting potential of Kurume azaleas differed during the year and the season: it was high from winter though spring and low from summer through autumn. In addition, the rooting potential suffered remarkable deterioration during the summer. This phenomenon seems to be typical for Kurume azaleas, and it is in contrasts with other woody plants that continued rooting slowly during the summer (Kishimoto et al. 1957, Hiroyasu 1965, Ohshima 1969, Roberts 1976, Alexander and Fairley 1983, Langlois et al. 1983, Yamashita 1989). Younger roots displayed higher RRPs, but fine white roots were 

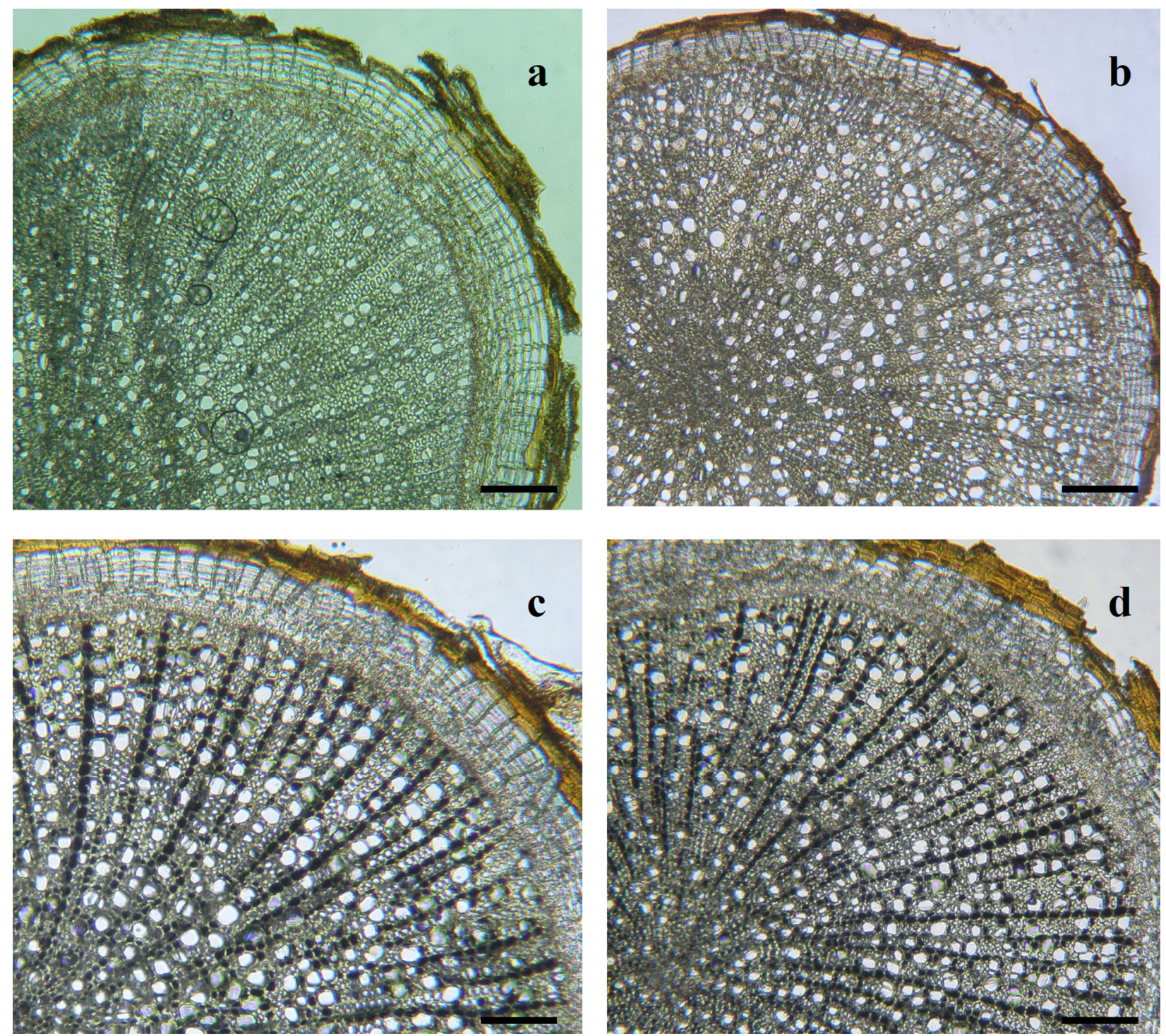

Fig. 2. Seasonal variations in reserve carbohydrate content of lignified root. a. June. b. August. c. December. d. February. Black dots in xylem parenchyma are amyloplast. Scale bars in figures are $110 \mu \mathrm{m}$ long.

unable to endure a long incubation (Yamashita 1989). Therefore, new root formation depends on physiological conditions of parental roots, not only on external conditions, such as temperature and moisture. Important factors related to rooting could be the mitotic activity of the tissues for new root initiation, reserve carbohydrate content (Yamashita 1989) and movements of endogenous growth substances (Kuraishi 1976, Russell 1977). A low rooting potential of Kurume azalea during summer might be mainly caused by a marked decrease in reserve carbohydrates during this season. In fact, NAA application was not effective to induce rooting during summer. Mechanisms of the extreme restriction of root generation during summer must be studied physiologically and morphologically in greater detail.

In Kurume azaleas, seasonal variation in rooting potential might be a major factor determining damage from various stresses. The cultivar "Chikushibeni" differs genetically from the original Kurume azaleas: it was obtained by crossing original Kurume azaleas with introduced "Karafune" azaleas. Consequently, the rooting peculiarity of this hybrid must be confirmed using other original Kurume azaleas. Furthermore, relationships between Kurume azaleas' rooting peculiarity and its susceptibility to environmental stresses must be verified using diverse cultivars under controlled conditions.

\section{References}

Alexander IJ, Fairley RI 1983 Effects of N fertilization on populations of fine roots and mycorrhizae in spruce humus. Plant Soil 71: 49-53.

Arakawa A 1975 Conditions to grow in a field. In: Garden Life, ed., Wild native species of Rhododendron. Seibundoshinkosha, Tokyo, pp. 62-64. (in Japanese) 
Eis S 1968 Lateral root pruning - a promising forest nursery practice. Forest. Chron. 44: 12-13.

Hiroyasu T 1965 Nutritional and physiological studies on grapevine. I. Growth studies of the under-ground and above-ground parts of vines. J. Jpn. Soc. Hort. Sci. 30: 77-81. (in Japanese with English summary)

Horiguchi T 2002 The growth and physiology of Rhododendron spp., In: Nobunkyo ed., Encyclopedia of floriculture: Flowering trees and shrubs. Nobunkyo, Tokyo, pp. 191-193. (in Japanese)

Kishimoto Y, Matsuno H, Kawasaki S 1957 The periodical growth of citrus Unshiu-root (Citrus trifolia Stock). Kyushu Agric. Res. 19: 60-62. (in Japanese)

Kuraishi S 1976 Auxins. In: S. Kuraishi ed., Plant growth substances. Tokyo University Press, Tokyo, pp. 14-47.

Langlois CG, Godbout L, Fortin JA 1983 Seasonal variation of growth and development of the roots of five second year conifer species in the nursery. Plant Soil 71: 55-62.

Mullin RD 1966 Root pruning of nursery stock. Forest. Chron. 42: 256-264.

Mullin RD 1973 Root and top pruning of white spruce at the time of planting. Forest. Chron. 49: 134-135.
Ohshima T 1969 Ecological studies on root growth of mulberry Bull. Iwate Seric. Exp. Sta. 3: 1-27. (in Japanese with English abstract)

Roberts J 1976 A study of root distribution and growth in a Pinus sylvestris L (scots pine) plantation in east Anglia. Plant Soil 44: 607-621.

Russell SR 1977 Relationships between roots and shoots. In: Plant root systems. McGraw-Hill Book Company (UK) Ltd., London, pp.9-29.

Yamashita M 1989 Studies on root system and regrowth after root pruning in tea plants. Bull. Natl. Res. Inst. Veg. Ornam. Plant. Tea D2: 29-117. (in Japanese with English abstract)

Yamashita M, Okamoto A 2008 Root regeneration on incubated lignified roots of Kurume azaleas is correlated to tolerance to environmental stress. Acta Hort. 766:231-236.

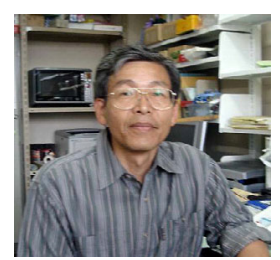

Dr. Masataka Yamashita is interested in responses of root growth and root system formation to environmental stresses, and is currently studying influences of root confinement on root growth and functions. 